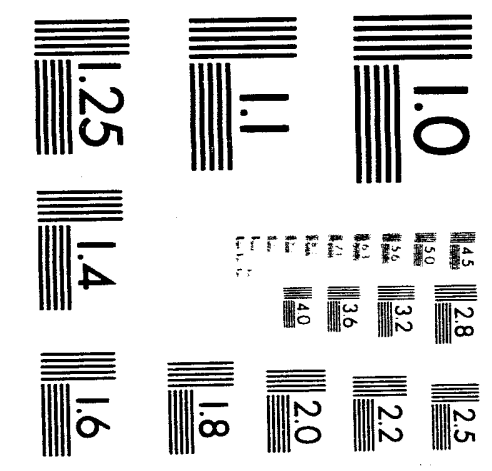



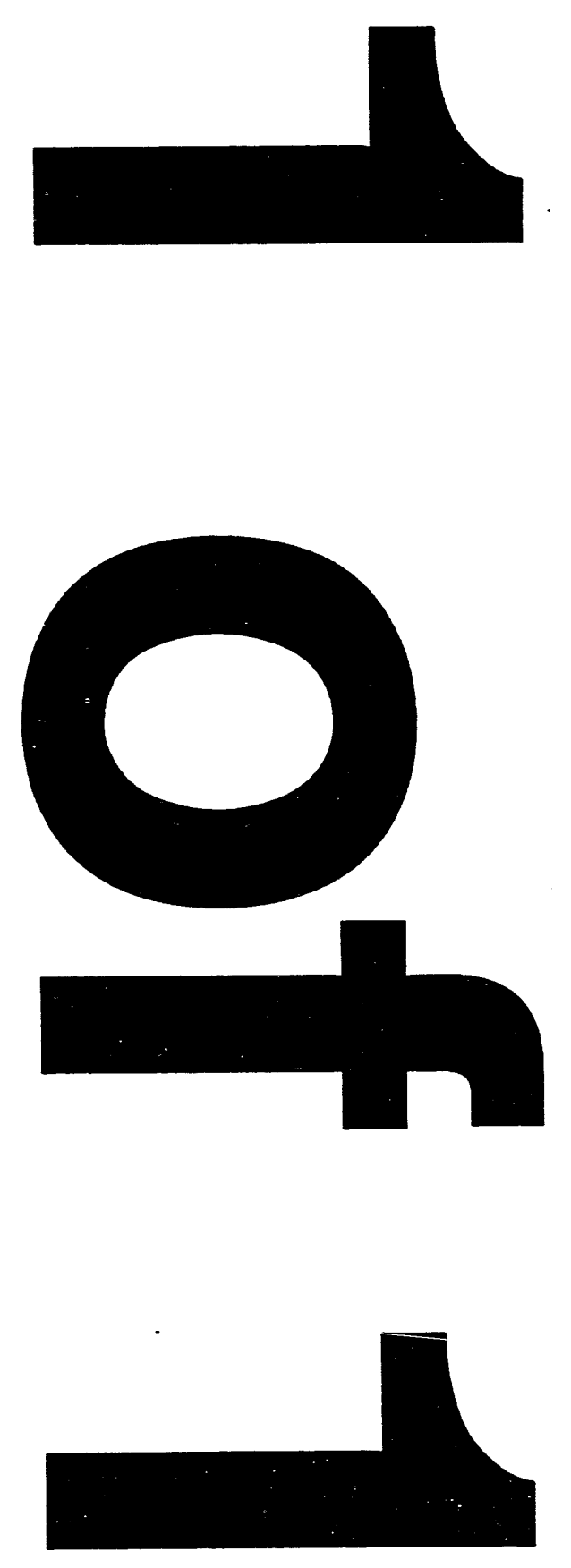


\section{Test Plan for the Rapid Geophysical Surveyor}

L. G. Roybal

Published June 1993

Idaho National Engineering Laboratory

EG\&G Idaho, Inc.

Idaho Falls, Idaho 83415

Prepared for the

U.S. Department of Energy

Office of Environmental Restoratlon and Waste Management

Under DOE Idaho Operations Office

Contract DE-AC07-76ID01570 


\section{Test Plan for the Rapid Geophysical Surveyor}

EGG-WTD-10875

Prepared by

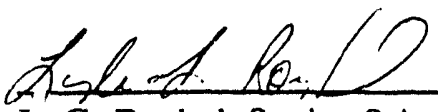

L. G. Roybal, Senior Scientist

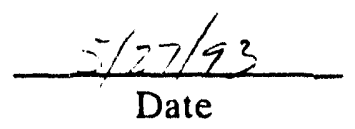

Applied Geosciences

Reviewed by

A.s Ante

N. E. Josten, Senior Scientist

$5 / 27 / 93$

Date

Applied Geosciences

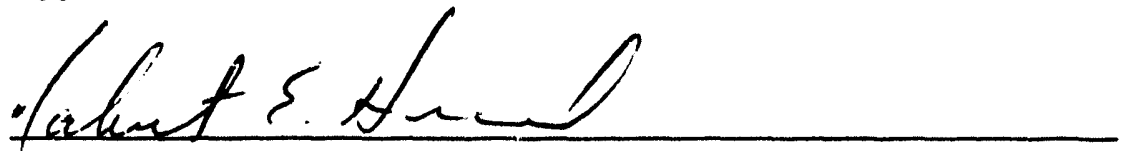

R. E. Heard, Project Manager

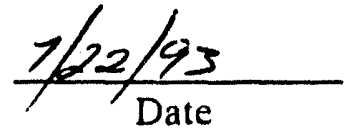

Buried Waste Integrated Demonstration

Approved by

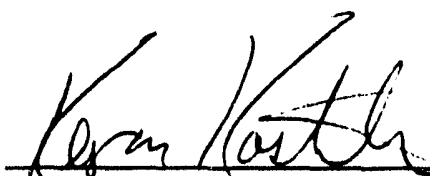

K. M. Kostelnik, Coordinator

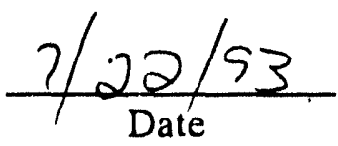

Buried Waste Integrated Demonstration 


\begin{abstract}
This document describes the test plan for demonstrating and testing a set of optically pumped cesium-hased total field magnetometers using the Rapid Geophysical Surveyor platform. The proposed testing will be used to assess the function of these magnetometers as deployed on the Rapid Geophysical Surveyor and evaluate the practical utility of high resolution magnetic data for supporting waste retrieval efforts.
\end{abstract}




\section{CONTENTS}

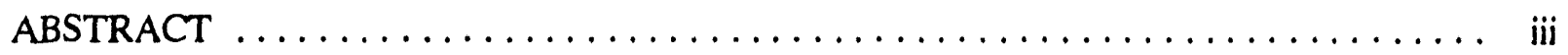

1. INTRODUCTION $\ldots \ldots \ldots \ldots \ldots \ldots \ldots \ldots \ldots \ldots \ldots \ldots \ldots \ldots \ldots$

1.1 Scope of Tests $\ldots \ldots \ldots \ldots \ldots \ldots \ldots \ldots \ldots \ldots \ldots \ldots \ldots \ldots \ldots \ldots$

1.2 Purpose and Objectives of Test $\ldots \ldots \ldots \ldots \ldots \ldots \ldots \ldots \ldots \ldots$

1.3 Technology Agreement $\ldots \ldots \ldots \ldots \ldots \ldots \ldots \ldots \ldots \ldots \ldots \ldots \ldots$

2. ORGANIZATION AND RESPONSIBILITIES $\ldots \ldots \ldots \ldots \ldots \ldots \ldots \ldots \ldots \ldots$

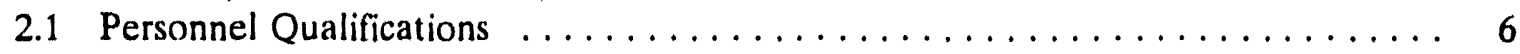

3. DESCRIPTION OF TESTS $\ldots \ldots \ldots \ldots \ldots \ldots \ldots \ldots \ldots \ldots \ldots \ldots \ldots$

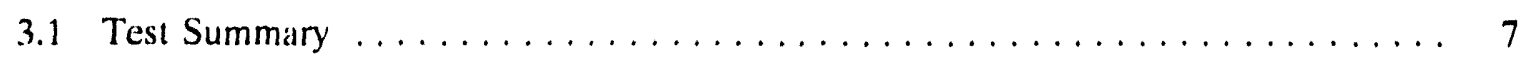

3.2 Test Method and Uncertainties $\ldots \ldots \ldots \ldots \ldots \ldots \ldots \ldots \ldots \ldots$

3.2.1 Phase 1-Magnetic Survey of Entire Cold Test Pit ............ 7

3.2.2 Phase 2-Magnetic Survey of the Retrieval Cell During

Overburden Removal ....................... 7

3.3 Uncertainty Considerations $\ldots \ldots \ldots \ldots \ldots \ldots \ldots \ldots \ldots \ldots \ldots \ldots$

3.4 Contingency Plan $\ldots \ldots \ldots \ldots \ldots \ldots \ldots \ldots \ldots \ldots \ldots \ldots$

4. SEQUENCE OF ACTIVITIES $\ldots \ldots \ldots \ldots \ldots \ldots \ldots \ldots \ldots \ldots \ldots \ldots \ldots$

5. SAMPLING AND DATA $\ldots \ldots \ldots \ldots \ldots \ldots \ldots \ldots \ldots \ldots \ldots \ldots \ldots \ldots$

5.1 Data Analysis of Phase 1 and 2 Surveys $\ldots \ldots \ldots \ldots \ldots \ldots \ldots \ldots$

6. DOCUMENT CONTROL $\ldots \ldots \ldots \ldots \ldots \ldots \ldots \ldots \ldots \ldots \ldots \ldots \ldots \ldots$

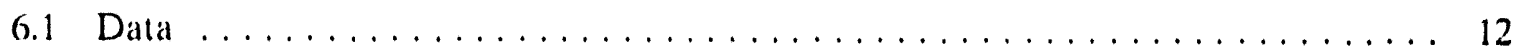

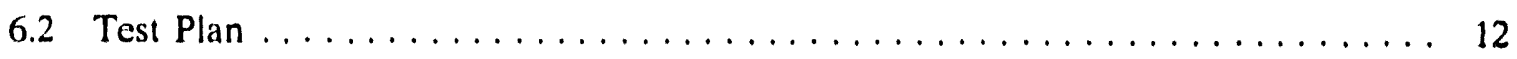

7. DATA REDUCTION, VALIDATION, AND VERIFICATION $\ldots \ldots \ldots \ldots \ldots \ldots$

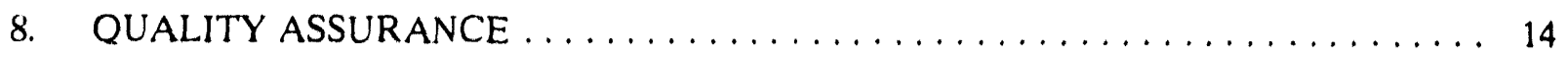

9. EQUIPMENT AND INSTRUMENTS $\ldots \ldots \ldots \ldots \ldots \ldots \ldots \ldots \ldots \ldots$ 
10. SUPPLIES, UTILITIES, AND FACILITIES $\ldots \ldots \ldots \ldots \ldots \ldots \ldots \ldots \ldots \ldots$

11. HEALTH AND SAFETY $\ldots \ldots \ldots \ldots \ldots \ldots \ldots \ldots \ldots \ldots \ldots \ldots \ldots$

12. RESIDUALS MANAGEMENTS $\ldots \ldots \ldots \ldots \ldots \ldots \ldots \ldots \ldots \ldots \ldots \ldots \ldots$

Appendix A-Geosciences Environmental Standard Operating Procedure for Land Magnetic Surveys . . . . . . . . . . . . . . . . . . . . . . .

Appendix B-Detailed Sequence of Activities for RGS Tests at the Cold Test Pit ....... B-1

\section{FIGURES}

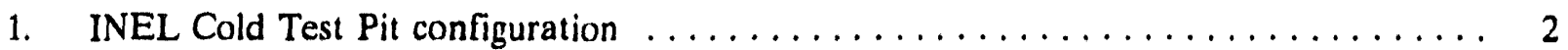

2. Retrieval cell configuration $\ldots \ldots \ldots \ldots \ldots \ldots \ldots \ldots \ldots \ldots \ldots \ldots \ldots$

3. Key RGS project personnel $\ldots \ldots \ldots \ldots \ldots \ldots \ldots \ldots \ldots \ldots \ldots \ldots \ldots \ldots$ 


\section{Test Plan for the Rapid Geophysical Surveyor}

\section{INTRODUCTION}

Standard geophysical techniques used to characterize buried waste sites include the use of magnetic surveys to delineate ferrous metallic waste. The collection of ground-based magnetic data is generally tedious and expensive. The Rapid Geophysical Surveyor (RGS) approach provides an automated method for collecting magnetic data that (a) allows surveys to be completed faster and (b) produces higher data density than conventional surveys. The increased speed of data acquisition yields cost savings, and higher data fidelity increases the information content of the data.

The RGS was successfully demonstrated using fluxgate vector magnetometers during fiscal year 1993. This test plan describes a program to evaluate the RGS using cesium total field magnetometers. The tests will be conducted on a controlled site that will provide the opportunity to assess the function of the total field system and evaluate the practical utility of densely spaced magnetic data for determining important characteristics of buried waste.

This section provides an introduction to the test plan, scope of the test, purpose and objectives of the test, and technology agreement with the Buried Waste Integrated Demonstration (BWID).

\subsection{Scope of Tests}

The Idaho National Engineering Laboratory (INEL) Cold Test Pit simulates buried waste configurations that may be encountered during characterization/remediation efforts on buried waste at U.S. Department of Energy (DOE) sites. Figure 1 shows the location of the Cold Test Pit including the 1992 addition of a characterization cell and four retrieval cells. A diagram of the retrieval cells is shown in Figure 2. A series of surveys will be performed at the original pit and retrieval cells.

Phase 1 of the RGS demonstration at the INEL will perform magnetic characterization of the entire Cold Test Pit area before scheduled retrieval activities. Phase 2 of the RGS demonstration will characterize a smaller test site before and alter removal of soil overburden. Demonstrations of the Remote Excavation System (RES) and Remole Characterization System (RCS) are scheduled in conjunction with the RGS demonstration. The RES will provide a means to remove layers of soil overburden in the retrieval cell of the Cold Test Pit. Magnetic surveys of the retrieval cell with the RCS and RGS will be performed at ground level and al 1 li 9 in. and 3 li 6 in. below initial ground level as overburden is removed.

\subsection{Purpose and Objectives of Test}

The purpose of this test is to evaluate the hasic function of the RGS (equipped with optically pumped cesium total field magnetometers) and assess the performance of the system with respect to three characterization objectives:

1. Identification of pit boundaries 


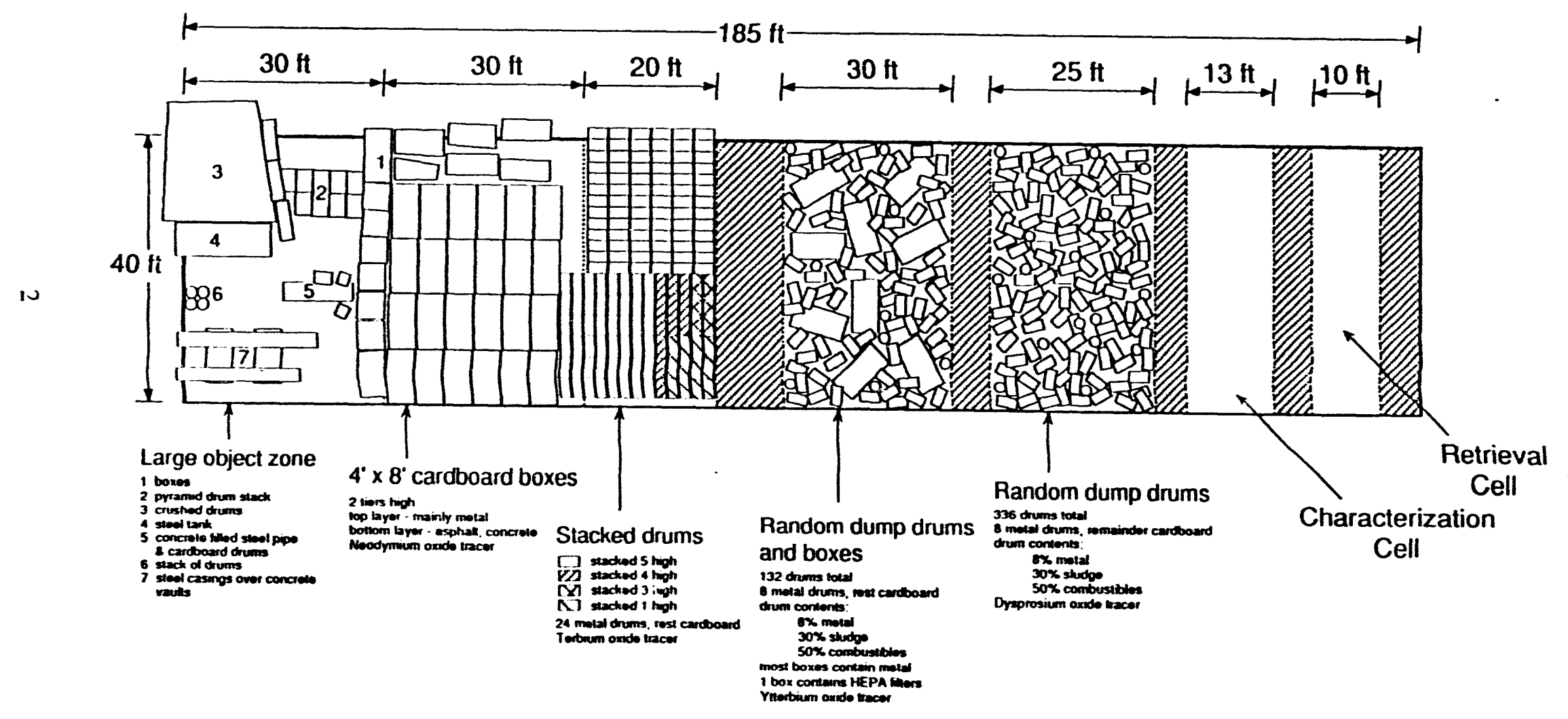

Figure 1. INEL Cold Test Pit configuration. 

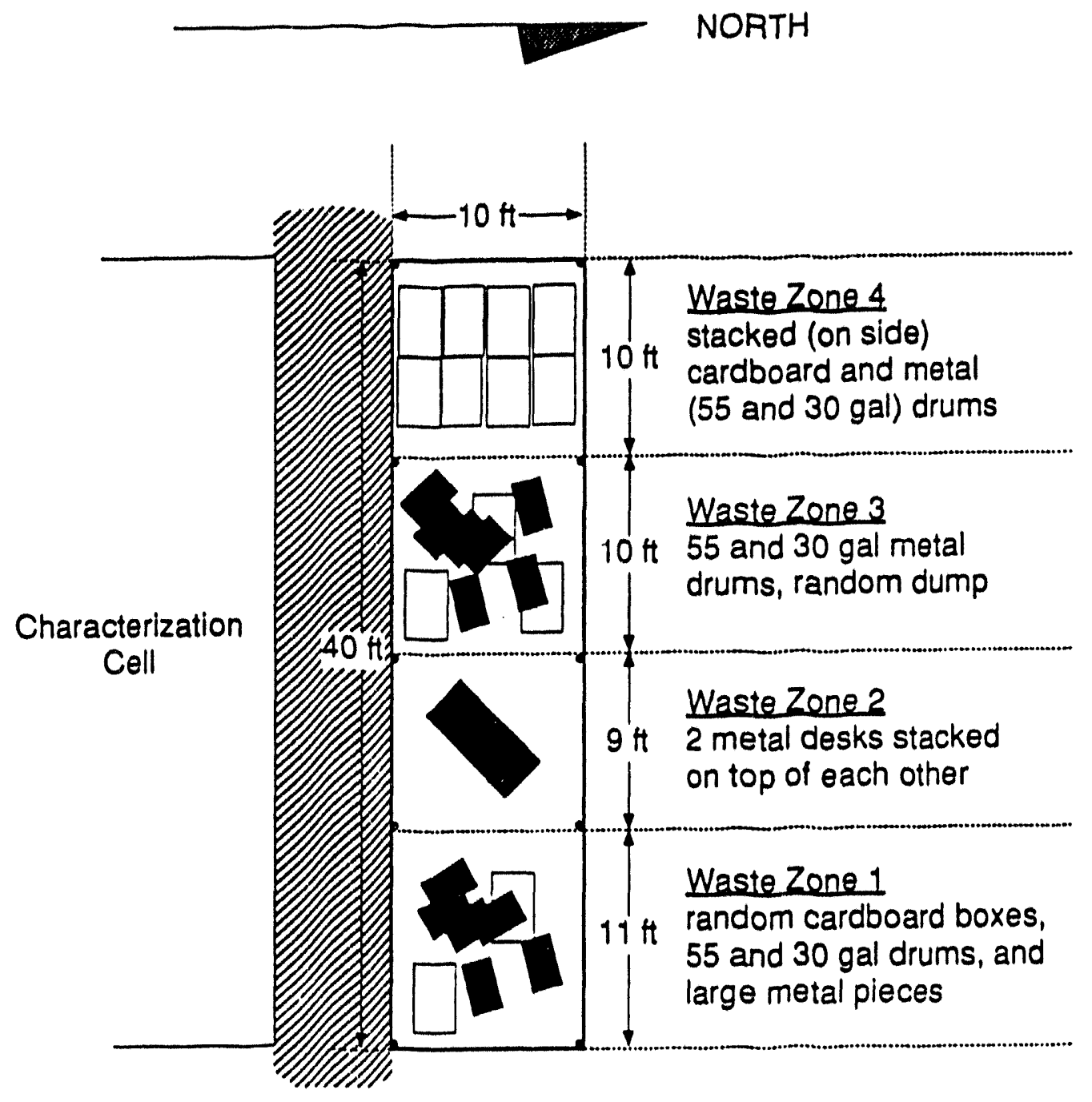

- 4 inch diameter ABS corner marking pipe (12 H length)

Figure 2. Retrieval cell configuration. 
2. Estimation of depth to metallic waste

3. Estimation of depth to basalt.

Determinations of pit boundaries and depth to waste will be developed through interpretation by a qualified geophysicist following compilation of the magnetic data acquired by the RGS. The basis for these interpretations will be documented in the linal evaluation report.

Basalt depth estimates using magnetic data are theoretically possible but are rarely achievable in practice on the scale of a test pit, particularly in cases where the magnetic data are dominated by signatures from buried metallic waste. Nonetheless, basalt depth estimates will be attempted and discussed in the final evaluation report.

\subsection{Technology Agreement}

The technology agreement with the BWID Program is as defined in EG\&G Idaho, Inc. Form 724, "Work Package Documentation." for work package number 3Y516()6()1, "Rapid Geophysical Surveyor." 


\section{ORGANIZATION AND RESPONSIBILITIES}

Key project personnel are shown in Figure 3. Ultimate authority and responsibility for the project belongs to L. G. Roybal of EG\&G Idaho's Applicd Geosciences Unit. Geophysical expertise will be provided by N. E. Josten and G. S. Carpenter of the Applied Geosciences Unit. N. G. Boyce of the Nondestructive Materials Characterization Unit is responsible for modifying the RGS platform to accommodate the cesium magnetometers. This work will he performed at the Idaho Research Center Model Shop. R. G. Berg of the Electrical Technicians Unit is responsible for modifying the electrical and software aspects of the RGS to handle the new magnetometers.

The RGS demonstration described in this test plan will take place at the INEL Cold Test Pit, located near the Radioactive Waste Management Complex. The Cold Test Pit is a nonhazardous, simulated waste site used for testing remedial technologies. No hazard monitoring or surveillance is required to conduct work at this site. Standard EG\&G Idaho company health and safety training are required for personnel working at the Cold Test Pit. Radiation worker and Occupational Safety and Health Administration (OSHA) 40 Hour training are not required.

The RGS demonstration will be conducted in eoncert with the RCS and RES demonstrations. All three technologies have been lunded by the BWID Program. The RGS demonstration will be coordinated by R. E. Heard. BWID Demonstration Projecl Manager (BWID demonstration) and R. A. Hyde, Buried Waste Roboties Coordinalor (RES and TCS demonstrations).

\section{Buried Waste Integrated Demonstration \\ Project Manager \\ R. E. Heard}

\section{Principal Investigator}

L. G. Roybal

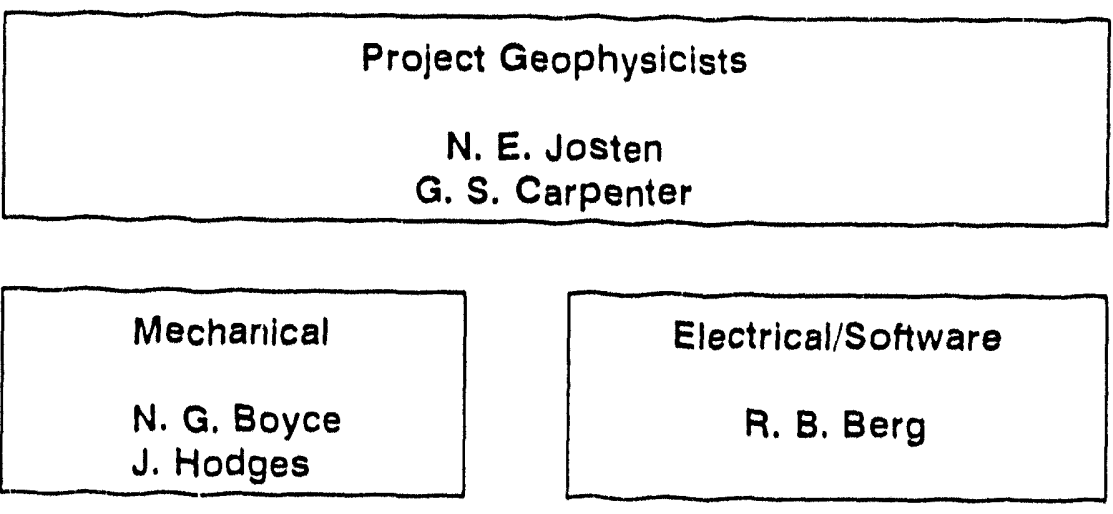

Figure 3. Key RGS project personnel. 


\subsection{Personnel Qualiflcations}

No special training or qualifications are required for personnel performing the RGS testing except for persons conducting field work, data reduction, and data interpretation. Persons performing these activities will be qualified geophysicists as described in the Standard Operating Procedure for Land Magnetic Surveys (see Appendix A). 


\section{DESCRIPTION OF TESTS}

As previously described, the RGS demonstration will assess the proper function of cesium magnetometers as deployed from the RGS platform and will evaluate the practical utility of densely sf aced magnetic data for determining several important characteristics of buried waste. The demonstration will involve two phases. The first phase will test the basic function of the cesium magnetometers as deployed on the RGS platform. The second phase will involve collecting and analyzing a high-precision magnetic data set to determine capabilities for discerning pit boundaries, depth to waste, and depth to basalt.

\subsection{Test Summary}

The location, duration, and dates for the RGS tests are summarized below.

\begin{tabular}{llll} 
Test & Location & Duration & \multicolumn{1}{c}{ Schedule } \\
\hline Phase 1 & Cold Test Pit & 1 day & June 1, 1993 \\
Phase 2 & Retrieval cells & 4 days & June 7 to 10, 1993
\end{tabular}

\subsection{Test Method and Uncertainties}

This section gives a general description of the planned RGS tests. Specific procedures are presented in Appendix B.

\subsubsection{Phase 1-Magnetic Survey of Entire Cold Test Pit}

The Phase 1 survey will consist of a full survey of the Cold Test Pit on a nominal $1 \times 1$-ft grid. Vertical gradient magnetic data will be collected using EG\&G Idaho Geometrics cesium magnetometers. The purpose of the Phase 1 test is to establish the basic function of the cesium magnetometers mounted on the RGS platform. This test is performed before evaluation of the practical capabilities in Phase 2. The assessment of proper function will be conducted based on comparison of the RGS data with a previously collected "standard" magnetic data set and by evaluating the repeatability of data collected by the RGS on successive, identical surveys.

\subsubsection{Phase 2-Magnetic Survey of the Retrieval Cell During Overburden Removal}

The Phase 2 survey will consist of three surveys of the retrieval cell as follows:

1. Survey before excavation

2. Survey after removal of $1 \mathrm{ft} 9 \mathrm{in.} \mathrm{of} \mathrm{soil}$

3. Survey after removal of an additional 1 fi 9 in. of soil (total of $3 \mathrm{ft} 6 \mathrm{in}$.).

All three surveys will be conducted on a nominal $1 \times 1-\mathrm{ft}$ grid. The retrieval cell surveys will be repeated five times to demonstrate repeatability and aid in data analysis during data processing. 
Following data collection, data will be processed and analyzed to determine retrieval cell boundary locations, depth to the top of waste and, if possible, depth to basalt. This analysis will be performed on each of the three data sets. Interpretations will be compared with the known locations of simulated waste in the retrieyal cell as a means to assess the practical utility of the magnetic data sets in a retrieval scenario.

\subsection{Uncertainty Considerations}

Factors affecting the uncertainty in determining pit boundaries, top of waste, or depth to basalt using magnetic data include (in order of importance):

1. Subjective nature of interpretation

2. Accuracy of sensor positioning and map generation

3. Accuracy of the magnetic sensor elements.

Interpretation, because of its subjective nature, forms the largest elcment of uncertainty in waste site characterization based on magnetic data. Complex magnetic fields arising from the presence of multiple, closely spaced, strongly magnetized objects in the subsurface preclude the effective use of simple, automated interpretation schemes. This places the burden of decision making on the subjective interpreter. Uncertainty in the interpretation of the RGS data will be assessed through comparison of final interpreted results to known lncation of objects in the retrieval cell. For this evaluation to be meaningful, it is crucial that the basis for the interpretations be clearly described and illustrated in the final evaluation report.

The remaining factors affecting uncertainty relate to the quality or "correctness" of the magnetic data that the interpreter uses for analysis. Of the two factors affecting data quality, the accuracy of the magnetic sensor elements is normally insignificant provided that the sensors function properly. For the RGS testing, proper sensor function will be evaluated hy comparing the Phase 1 data set with a standard data set previously collected at the Cold Test Pit.

A second and more important factor alfecting data quality relates to positioning. Positioning errors result from imprecise tracking and recording of sensor location and spatial undersampling. For the RGS demonstration, errors from imprecise sensor location will be evaluated by comparing repeated surveys of the same area during Phase 1 tests. Errors from undersampling create distorted "apparent" magnetic anomalies that can be significantly diflerent from "true" magnetic anomalies. Computer gridding and mapping can cause further distortions. The RGS was designed specifically to enable cost effective collection of properly sampled data. The planned $1 \times 1$-ft grid will provide adequate spatial sampling.

\subsection{Contingency Plan}

Tests will be discontinued in the event of weather conditions that (a) seriously compromise test results or (b) cause an equipment lailure or an accident or emergency at the testing site. The BWID 
project manager will evaluate the situation to determine the most appropriate method to meet the test objectives.

In the event that the RGS field activities deviate from this test plan, test procedures may be modified in the field. Any modification of procedures will be approved by L. G. Roybal or a designated alternate. 


\section{SEQUENCE OF ACTIVITIES}

The detailed sequence of activities for the Phase 1 and 2 tests is presented in Appendix B. The Phase 1 test is scheduled to take place before commencement of the major 1993 field activities at the Cold Test Pit. Except in the event of adverse weather, the Phase 1 tests require no coordination with the RCS, RES, or any other scheduled demonstrations at the Cold Test Pit. The Phase 2 test must be closely coordinated with the RCS and RES demonstrations. The basic sequence of events for Phase 2 tests is as follows:

1. RGS and RCS survey of retrieval ceil

2. Removal of $1 \mathrm{ft} 9$ in. of overburden

3. Resurvey with RGS and RCS

4. Removal of an additional 1 it 9 in. of overhurden

5. Resurvey with RGS and RCS. 


\section{SAMPLING AND DATA}

A series of general guidelines and procedures applicable to conventional land magnetic surveys have been developed by Applied Geosciences and are provided in Appendix A. Procedures specific to the use of the RGS are described below.

The RGS is designed so that the user can tailor the hardware and software associated with the RGS in the field. Hardware adjustments include sensor height above ground level and sensor spacing between profiles. The lower sensor in each profile will be placed as close to the ground as practical to obtain the maximum signal-to-noise ratio. The sensor horizontal spacing will be adjusted to correspond to the survey profile distance that is nominally $1 \mathrm{ft}$. The RGS incorporates a menu-driven operating system to allow the user to adjust the sample spacing along profiles and profile line number. These will be set and initialized before each survey. The sample spacing will be adjusted so that data are collected at nominal 1-ft increments along the profiles.

Before collection of individual profiles, the RGS requires an initialization that places the surveyor at a known location. This can be viewed as initializing the measuring wheel subsystem. Once this is complete, the dala are collected automatically by the RGS until the end of the survey line. Although the RGS is capable of collecting data in : bidirectional mode, all data will be collected unidirectionally because of the small number and short length of profiles.

The data will be collected in two phases corresponding to a initial survey of the entire Cold Test $P$ it and individual surveys of the retrieval test cell during the RES excavation Jemonstration. The detailed sequence of activities for the Phase 1 and Phase 2 lests is presented in Appendix B.

\subsection{Data Analysis of Phase 1 and 2 Surveys}

Analysis and interpretation of the Phase 1 data will be limited to map compilation and presentation of the vertical gradient magnetic data. These maps will be produced to scale for comparison with existing magnetic data sets of the Cold Test Pit.

Analysis and interpretation of the Phase 2 data will include map compilations of magnetic data for each of the three survey ground levels. Pit houndaries will he interpreted and documented on clear overlays for each map. Depth wo sorurce calculations will also be performed and documented on the clear overlays. 


\section{DOCUMENT CONTROL}

\subsection{Data}

The RGS will generate a large amount of data in a very short period of time. Once the data are transferred from the surveyor to a personal computer (PC), a permanent archive of the data set will be made on floppy disk(s). The floppy disk(s) will he write protecled and placed in the RGS project file. The BWID Program will also be given the raw and processed data for inclusion into the BWID Technical Information Management System.

\subsection{Test Plan}

The test plan will be reviewed and approved by Waste Technology Development (WTD) personnel. All changes to the test plan before actual ficld testing will be approved by WTD personnel. 


\section{DATA REDUCTION, VALIDATION, AND VERIFICATION}

The data provided from the RGS are digital values of the total magnetic fields measured by each of the magnetometers in the system. Derived data of interest will include the vertical magnetic gradient of the total field. This is a simple computation based directly on the total field measurements as shown in equation 1.

$V G=\frac{(\text { Mag1 }- \text { Mag2) }}{L}$

where

$$
\begin{aligned}
& \text { VG }=\text { vertical gradient } \\
& \text { Mag1 }=\text { lower magnetometer } \\
& \text { Mag2 }=\text { upper magnetometer } \\
& \mathrm{L}=\text { distunce between magnetometers. }
\end{aligned}
$$

The magnetic data stored in the RGS will be downloaded into a portable PC for field processing after the survey is completed. A preliminary color magnetic mup will be generated in the field at the Cold Test Pit. It is anticipated that this will he available within 20 minutes after the data are download from the RGS. This assumes that a 80486 class, color portable PC is available for the field test.

Once the data are determined valid in the field, the process of plotting and mapping the data will begin in Idaho Falls. Idaho. Magnetic maps will be prepared and compared to existing ground surveys. Interpretation of the data will he performed hy N. E. Josicen and G. S. Carpenter of the A.pplied Geosciences Unit. Map compilation, which includes gridding and contouring of magnetic data, will be done with the Geosoft Mapping software owned by Applied Geosciences. The users manual for Geosoft is available for inspection by BWID personnel as required. 


\section{QUALITY ASSURANCE}

The test effort will be performed in accordance with the requirements of Quality Level B as defined in the EG\&G Idaho Quality Manual. The WTD Quality Program Plan, based on QPP.377 and site related requirements, will govern the activities associated with the testing of the surveyor. The magnetometer system, which was purchased specifically for this project, conforms to Quality Level B equipment. The magnetic equipment has a stated noise level of 0.01 nanotesla (gamma). The positioning device integrated into the surveyor has achieved $0.5 \%$ accuracy in previous field tests over terrain similar to that at the Cold Test Pit.

All field activities will be documented in loghooks that are similar to those described in the procedures in Appendix $A$. 


\section{EQUIPMENT AND INSTRUMENTS}

The RGS is the only equipment required for this ficld test. It incorporates a number of off-theshelf components. The magnetometers are optically-pumped, cesium EG\&G Idaho Geometrics instruments with a stated sensitivity to 0.01 nanoTesla. By contrast, the magnetic anomalies generated by typical buried waste generally range between 100 (1) 200) nanoTesla.

The RGS subsystems are described in detail in the Rapid Geophysical Suneyor-Final Report, EGG.WTD-10566, January 1993. 


\section{SUPPLIES, UTILITIES, AND FACILITIES}

No additional supplies, utilities, or facilities are required to conduct the tests at the Cold Test Pit. 


\section{HEALTH AND SAFETY}

The anticipated activities for the demonstration test are considered routine with no health or safety dangers envisioned. 


\section{RESIDUALS MANAGEMENTS}

The are no wastes anticipated from this activity. 
Appendix A

Geosciences Environmental Standard Operating Procedure for Land Magnetlc Surveys 
A-2

$$
\text { A. } 2
$$


GEOSCIENCES ENVIRONMENTAL

STANDARD OPERATING

PROCEDURES MANUAL
TITLE: LAND MAGNETIC SURVEYS

AUMBER: 11.14 .3
ISSUE DATE: $8 / 08 / 92$

\subsection{PURPOSE AND SCOPE}

This procedure provides general instructions for field personnel under the direct supervision of a Project Geophysicist to perform land magnetic surveys. The purpose of a land magnetic survey is to record variations in the intensity of the earth's magnetic field. The recorded data may be used for subsequent geologic interpretations and/or detection of buried ferrous metal.

\subsection{PROCEDURE}

\subsection{Quality Assurance}

Activities conducted according to this procedure will be in compliance with an investigation-specific Quality Assurance Project Plan (QAPP) or other project level plan as applicable.

\subsection{Health and Safety}

Activities conducted according to this procedure will be in compliance with an investigation-specific Health and Safety Plan and Safe Work Permits as required.

\subsection{Training}

The Project Geophysicist supervising the land magnetic survey must have relevant experience in the acquisition, processing and interpretation of geophysical data.

Field Technicians must be trained to properly operate the specific geophysical equipment that is used for the survey. This training may be provided by the qualified Project Geophysicist.

\subsection{General}

Measurements of the earth's magnetic field are made at discrete station locations using a portable magnetometer. The total magnetic field and/or the vertical gradient of the total field may be measured.

Measurements are normally made along linear profiles, with station spacing dependent on the estimated depth to targets. Normally, the maximum distance between stations should be from one-half to one-fourth the estimated target depth.

Areal coverage is produced by making measurements along additional profiles, usually parallel to each other. Profile spacing will depend on the nature of the targets, including the depth of the targets and their expected distribution in the subsurface. 
GEOSCIENCES

ENVIRONMENTAL

STANDARD OPERATING

PROCEDURES MANUAL
TITLE: LAND MAGNETIC SURVEYS

NUMBER: 11.14 .3

ISSUE DATE: $8 / 08 / 92$

Interpretations of the magnetic data are based on the identification of anomalous features in the measured magnetic data. The shape, amplitude, and steepness of magnetic anomalies are features that may be used to help identify the causative body. Independent information such as geology, other geophysical data, and cultural feature maps are used to constrain the interpretation of the magnetic data.

\subsection{Equipment}

\subsubsection{Description of Equipment}

The magnetic sensors used most often for environmental work are proton precession magnetometers and magnetic gradiometers. Proton precession instruments measure the total magnitude of the earth's magnetic field at one or two points, corresponding with the sensor element location(s). A proton precession magnetometer is sensitive and stable to within \pm 1 gamma over the range of 20,000 to 90,000 gammas. The measurement technique is based on the fact that protons will precess about an external magnetic field at a frequency that is proportional to the external field strength. The precession frequency of the protons is related to the magnetic field strength through the proton gyromagnetic ratio, which is a fundamental atomic constant. Measuring the precession frequency of the protons allows the total magnetic field to be determined simply by dividing the observed precession frequency by the proton gyromagnetic ratio. Vertical gradient data is produced by computing the difference between the total field at the two sensor elements, and dividing by the distance between the elements.

\section{a. Sensor unit}

The sensor unit consists of two proton precession sensors spaced a fixed distance apart. Each sensor outputs an oscillating electric current that is transmitted to the control unit by means of a signal cable. The sensor unit is mounted on a non-ferrous aluminum rod. Sections may be added to the rod to vary the height of the sensors above the ground. The sensor unit is marked with a North arrow so that it can be oriented for maximum signal to noise ratio.

\section{b. Signal cable}

The signal cable is a durable, insulated conducting cable. For some magnetometers, the length of this cable is calibrated and changing the cable length will adversely affect data quality. 


\section{GEOSCIENCES}

ENVIRONMENTAL

STANDARD OPERATING

PROCEDURES MANUAL

\section{TITLE: LAND MAGNETIC SURVEYS}

NUMBER: 11.14 .3 ISSUE DATE: $1 / 02 / 92$

c. Control unit

The control unit contains the electronics that analyze the sensor outputs, compute total magnetic field values for each sensor, and generate statistical information on the accuracy of the data. The control unit also contains a keyboard for programming the magnetometer function, a display for monitoring the data, and an internal memory for storing data values. An output port on the control unit is used to transfer data to a digital computer.

\subsubsection{Preparation of Equipment}

The following equipment checks and set-up procedures shall be performed prior to data acquisition. These checks shall be documented in the field notebook.

a. The control unit, sensors, and connecting cable shall be assembled per the instructions in the instrument's operating manual.

b. Check that batteries are adequately charged and charge or replace as required

c. The magnetometer shall be programmed for operation in total field or vertical gradient mode, and for internal recording of location coordinates, as per the instructions in the instrument's operating manual.

d. The sensitivity of the 1 and magnetometers is preset by the manufacturer. The measurement technique of the magnetometers is based upon the principle of proton precession and no calibration is required.

e. In order to adjust the magnetometer to the magnetic field range at the survey area, tuning shall be performed prior to data acquisition on the first day of the survey. Tuning shall be performed in accordance with the instructions in the instrument's operating manual.

\subsection{Field Procedure}

\subsubsection{Location of Magnetic Survey Lines}

a. The Project Geophysicist shall determine the proposed locations of magnetic survey lines. Locations shall be noted on a line location map. 
GEOSCIENCES

ENVIRONMENTAL

STANDARD OPERATING

PROCEDURES MANUAL
TITLE: LAND MAGNETIC SURVEYS

NUMBER: 11.14 .3 ISSUE DATE: $1 / 02 / 92$

b. The accuracy and precision of the line location survey will depend on the objectives for the magnetic survey. Locations may be determined by optical surveying, or by taped measurements. The survey should be tied to at least one known point, which should be identified in the field notebook. Final station coordinates should be reported using a standard US Geological Survey map projection.

c. If lines are to be optically surveyed, the line location map shall be furnished to the licensed surveyor. Upon completion of surveying, the surveyor will provide the Project Geophysicist with a map showing the locations and stationing of all magnetic survey lines. If required, the surveyor will place non-metallic stakes or flagging to identify station locations.

d. If line locations are not optically surveyed, they shall be determined by the field Technician using taped measurements. The method for laying out the magnetic survey lines shall be noted in the field notebook. Non-metallic stakes and flagging will be placed as required.

e. As work progresses, additional lines may be specified by the Project Geophysicist. If specified, the additional lines should be listed or added to the line location map. Any changes to the field operation based on field conditions shall be approved by the Project Geophysicist and shall be documented in the field notebook.

\subsubsection{Data Acquisition}

a. The Project Geophysicist shall verify that the magnetic survey lines have been located as specified, and that field conditions have been noted in the field notebook.

b. A base station should be chosen within the area of the magnetometer operations. The base station location should be free from the influence of conditions which might affect readings (e.g. fences, metallic utilities or powerlines). Base station readings shall be used to assess the effect of diurnal variations in the earth's magnetic field. Such readings shall be taken throughout the day at sufficient intervals (normally not exceeding 2 hours). 
GEOSCIENCES ENVIRONMENTAL STANDARD OPERATING PROCEDURES MANUAL
TITLE: LAND MAGNETIC SURVEYS

NUMBER: 11.14 .3

\section{ISSUE DATE: $\quad 1 / 02 / 92$}

c. Field stations shall be established along survey lines at intervals dependent upon the purpose of the survey.

d. Readings shall be taken at each station. To assure optimum results, sensors are marked with an arrow or the letter "N". This mark should be pointed approximately toward magnetic north.

e. Data obtained with the magnetometer shall be stored in the instrument's internal memory and transferred to a personal computer at the conclusion of the field day. After transfer to a computer, data shall be stored on both hard disk and floppy diskette (if avallable), and a hardcopy listing of the data shall be produced.

\subsubsection{Documentation of Field Records}

The following information shall be documented in at least one field notebook entry:

1. profect name

2. project location

3. magnetometer type and identification number.

The following information shall be documented in the field notebook on a dally basis:

1. date

2. type of survey (total field or gradiometer)

3. line numbers completed

4. station numbers completed

5. base station location and times of reoccupation

6. diskette numbers if applicable

7. locations of cultural features or other debris observed during data acquisition that are suspected to affect the magnetic readings collected during daily operations

8. weather conditions. 
GEOSCIENCES

ENVIRONMENTAL

STANDARD OPERATING

PROCEDURES MANUAL
TITLE: LAND MAGNETIC SURVEYS

NUMBER: 11.14 .3

\subsection{Data Reduction}

\subsubsection{General}

Since field readings taken during land magnetic surveys are already expressed in magnatic total field units (gammas), the only data reduction required is the application of diurnal corrections, when necessary. Diurnal corrections are not required for vertical gradient surveys.

\subsubsection{Diurnal Corrections}

Base station readings shall be complled and plotted so that the need for diurnal correction can be determined. This determination will depend upon the purpose(s) of the project.

If diurnal corrections are necessary, a convenient reference value within the range of base station readings for survey lines shall be selected. Using this reference value, all station readings for survey lines shall be adjusted to correct for the diurnal variations.

a. If two successive base station values are above the reference value, a linear trend shall be determined for the corresponding time interval. All stations completed during that time interval shall be corrected by subtracting the difference between the linear trend value and the reference value, based on the time of the station reading.

b. If two successive base station values are below the reference value, a linear trend shall be determined for the corresponding time interval. All stations completed during that time interval shall be corrected by adding the difference between the linear trend value and the reference value, based on the time of the station reading.

\subsection{Data Processing}

\subsubsection{Analog Data Processing}

Final magnetic values may be plotted as profiles or contour maps. Profiles shall be generated using distance along each survey traverse plotted on the $x$-axis and magnetic field strength (gamma) or vertical gradient (gamma/meter) on the $y$-axis. Contour maps shall be generated by transferring magnetic values onto an appropriate plan map (or overlay of a plan map), and then contouring the data at an appropriate 
GEOSCIENCES ENVIRONMENTAL STANDARD OPERATING PROCEDURES MANUAL
TITLE: LAND MAGNETIC SURVEYS

NUMBER: 11.14 .3

contour level.

Locations of surficial or other known sources of anomalous magnetic fields (e.g. power lines, plpes, fences) shall be noted on the magnetic profiles or contour maps.

Alternatively these may be shown on an overlay of the plan map.

\subsubsection{Digital Data Processing}

Digital processing may be performed on data acquired using efther digital or analog recording methods. If analog data are to be processed digitally, the analog data shall be entered into a personal computer. The data may then be proflled and/or contoured.

Profiles shall be produced using commercially avallable software. Contour maps of the magnetic data shall be produced using commercially avallable software. Other techniques for processing and displaying digital magnetic data may be used as necessary.

\subsection{Data Interpretation}

\subsubsection{General}

Interpretation of the magnetic data shall be performed by, or under the direct supervision of the Project Geophysicist.

\subsubsection{Plotting of Known Magnetic Sources}

Known sources of anomalous magnetic values shall be noted on the proflles, contour maps, or contour-map overlays. These sources may include cultural features and geologic features such as rock outcrops and faults.

\subsubsection{Identification of Anomalous Trends}

Magnetic profiles shall be aligned to identify possible trends that may be indicative of buried metal or other targets of interest. Magnetic contour maps shall be analyzed to identify zones of anomalous magnetic field strength.

A comparison of magnetic survey results with cultural features and geologic features should be performed to evaluate obvious causes for the observed magnetic trends. The magnetic survey data should also be compared with any other avaliable geologic or geophysical data to aid in determining the causes for other observed magnetic trends. 
GEOSCIENCES

ENVIRONMENTAL

STANDARD OPERATING

PROCEDURES MANUAL
TITLE: LAND MAGNETIC SURVEYS

NUMBER: 11.14 .3
ISSUE DATE: $1 / 02 / 92$

\subsection{Documentation of Results}

Results of the magnetic data intorpretation shall be complled in a report. The form and scope of the report will depend on the purpose of the magnetic survey. The report shall include maps and profiles of the magnetic data, and a hardcopy listing of the data.

The report, maps, proflles and hardcopy listing shall be delfvered to the Fieid Data Coordinator for the Environmental Restoration Department. If required, diskettes of the digital data shall also be provided to the Data Coordinator. The information provided to the Data Coordinator shall be complete and sultable for loating into a data base.

\subsection{DEFINITIONS}

Project Geophysicist - qualified geophysicist having final responsibility for the survey design, data acquisition, interpretation, and reporting for the geophystcal survey. Qualifications are defined in section 2.3 above.

Field Technician - personnel performing varlous tasks during the geophysical survey under the direct supervision of the Project Geophysicist. Qualifications are defined in section 2.3 above.

Total Field Magnetometer - an instrument used to measure and record the earth's magnetic field intensity.

Total Field Gradiometer - an instrument composed of two magnetometers that measures and records the gradient of the earth's magnetic field intensity.

Cultural features - manmade structures such as fences, pipes, powerlines, butldings etc. that occur in the vicinity of a survey site and which may effect the recorded geophysical data.

\subsection{REFERENCES}

The following references provide general discussions of magnetometers, magnetic surveying and magnetic data interpretation.

Benson, R., R. A. Glaccum, and M. R. Noel, 1988, Geophysical Techniaues for Sensing Burled Wastes and Waste Miaration. Dublin, Ohio: National Water Well Association.

Breiner, S., 1973, Applications Manual for Portable Magnetometers, Sunnyvale, California: Geometrics. 


\section{GEOSCIENCES}

ENYIRONMENTAL

STANDARD OPERATING

PROCEDURES MANUAL

\section{TITLE: LAND MAGNETIC SURVEYS}

NUMBER: 11.14 .3

ISSUE DATE: $1 / 02 / 92$

Dobrin, M. B., 1976, Introduction to Geophysical Prospecting, New York: McGraw-Htill, Inc.

U. S. Environmental Protection Agency, 1987, A Compendlum of Superfund Field Operations Methods, U. S. Environmental Protection Agency Document PB88-181557.

Telford, W. M., L. P. Geldart, R. E. Sheriff, D. A. Koys, 1976, Apolied Geophysics, New York: Cambridge University Press. 


\section{Appendix B}

\section{Detalled Sequence of Actlvitles for RaS Tests at the Cold Test Pit}

B.1 


\section{Appendix B}

\section{Detalled Sequence of Activities for RGS Tests at the Cold Test Pit}

In this appendix, the detailed layout and procedure for the two phases of the Rapid Geophysical Surveyor (RGS) demonstration are described.

Phase 1-Magnetic survey of entire Cold Test Pit.

The Phase 1 Survey will be carried out through deployment of the RGS as follows:

1. Four corner stakes will be set 10 define the boundaries of the Phase 1 survey. These will be set using measuring tapes referenced to convenient survey controls already in place at the Cold Test Pit.

2. Measuring tapes will be strectehed and lixed alung the east and west boundaries of the staked area to establish start and stup points lior survey proliles. These tupes define the y-axis for the magnetic survey, with $y=0$ localed at the north end of the Cold Test Pit.

3. Beginning at the north end of the Cold Test Pit (i.c., at the retrieval cell), a third tape or reference rope will be stretched across the Cold Test Pil (perpendicular to the hase line tapes) at the point $y=0$.

4. Beginning at the east boundary of the survey area, the RGS will be profiled across the Cold Test Pit, visually following the profile reference lape, and collecting magnetic data at approximately $1 . f t$ intervals.

5. The RGS will be returned to the east houndary of the Cold Test Pit. The profile reference tape will be moved to the point $y=1 \mathrm{f}$, and a new profile will be collected in the manner described in ilem 4 ahove.

6. The entire Cold Test Pit will be surveyed along profiles spalced 1 fi aparti each profile will run east to west as described ahove, until the entire Cold Test Pit has heen surveyed.

7. The magnetic dalta will be dumped lo a portable personal compuler al intervals determined by onsite geophysicists 10 aceommodatc quality control and guard against data loss due to malfunctions.

8. If time permits, the entire Cold Test Pit (or a portion thereol) will he resurveyed using the same procedure as a means to evaluate repeatahility. 
Phase 2-Repeat surveys of the retrieval cell during excavation

The Phase 2 survey will be carried out through deployment of the RGS as follows:

1. Four corner stakes will be set to define the houndaries of the Phase 2 survey. These will be set using measuring tapes referenced to convenient survey control already in place at the Cold Test Pit.

2. Using procedures identical to those oullined for Phase 1 survey, the resieval cell will be surveyed along l-fit profiles running cist (o) west.

3. Following removal of an initial soil layer by the Remotc Retrieval System (RES), the retrieval cell will be surveyed with the RGS along $1-\mathrm{ft}$ profiles.

4. Following removal of a final soil layer by the RES, the retrieval cell will be resurveyed with the RGS along $1 \cdot \mathrm{ft}$ profiles. 

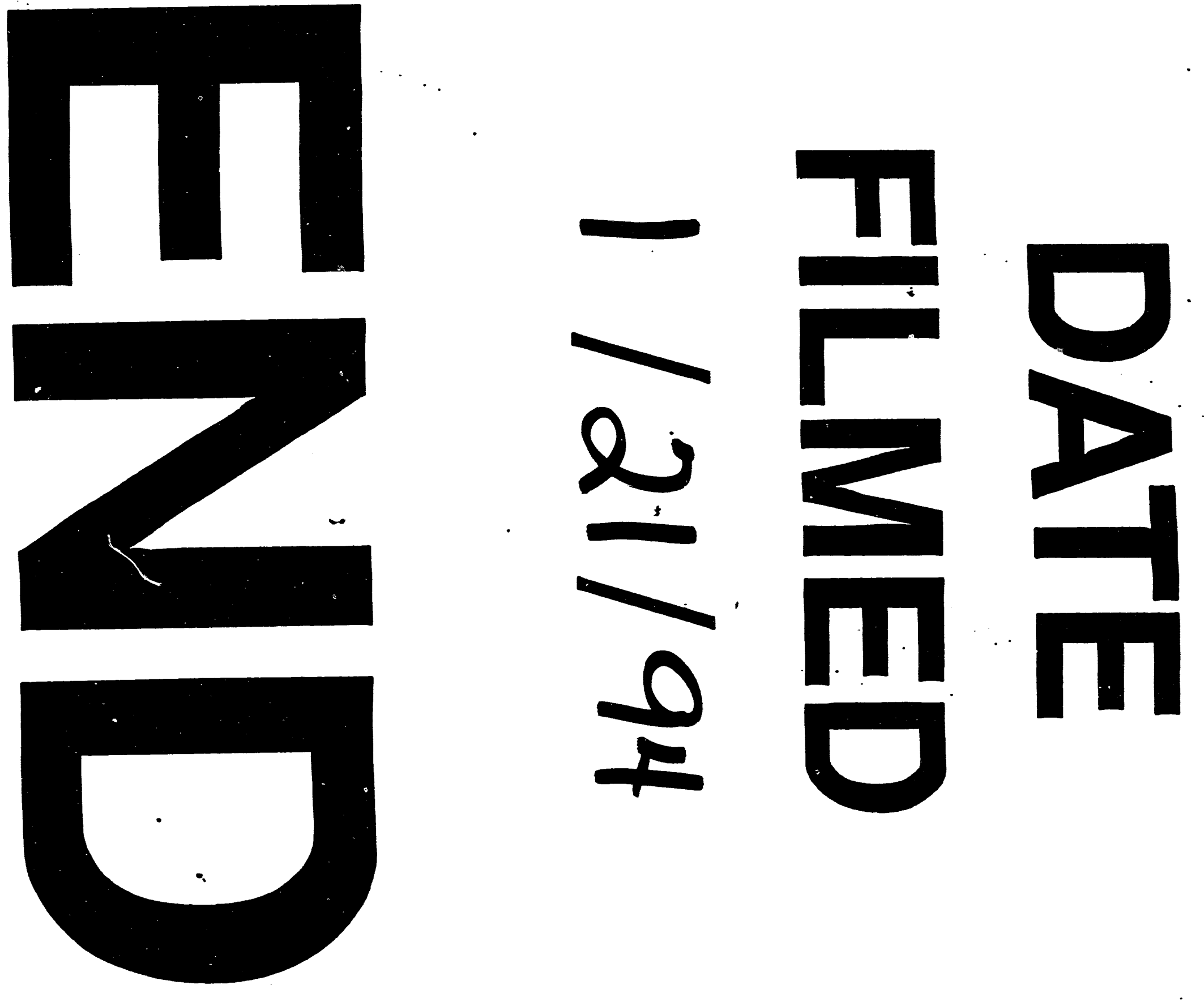

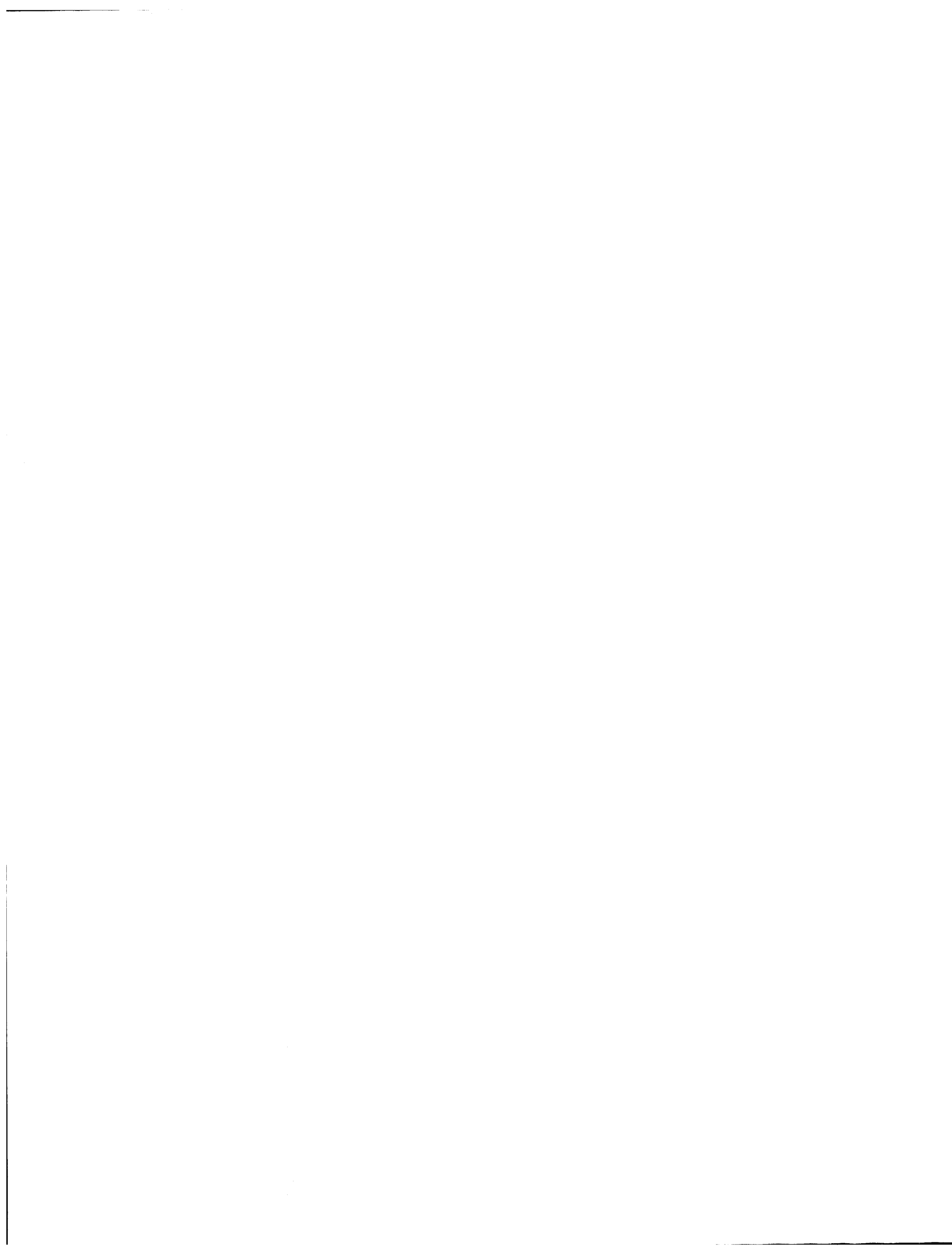